\title{
Validating Organizational Effectiveness: Exploring Criteria for Exemplary and Outstanding Local Conferences in the North American Division
}

\author{
Theodore Brown Sr., Ph.D. \\ Professor of Management and Leadership \\ Oakwood University \\ Department of Business and Information Systems \\ School of Business
}

\begin{abstract}
Organizations in various sectors of diverse domestic and global industries (profit and not-for-profit) (public or private) such as business, education, government, healthcare, military, religious, etc. operate in very competitive environments that require the highest levels of excellence in operational standards. Indicators of outstanding organizations (germane to a particular industry) may tend to use measurements such as an entity's certified audit reports; competitive advantage; financial indicators, market share; growth, expansion and/or retention; profitability; shareholder investment returns; stakeholder engagement and customer satisfaction surveys. Benchmarks to achieve these standards may also be found in gold star instruments such as the Malcolm Baldridge Award, Good-to-Great Organizations and Industry Best Practices. The basis for this qualitative exploration was instigated by sentiments that Seventh-day Adventist (SDA) local conferences may also aspire to emulate standards of excellence that are expected and exemplified in other exemplary organizations. Three critical questions this study will address are: (1) What are possible criteria and standards of organizational excellence and effectiveness? (2) What comprises an organization's effectiveness system? (3) What are the attributes of an effective and efficient organization? A qualitative design was utilized with data for this study selected, collected and analyzed (coding, patterns, trends and themes) from extensive open-ended questionnaires to targeted populations of NAD and Union conference CEOs (Chief Executive Officers/Presidents), CAOs (Chief Administrative Officers/Executive Secretaries) and CFOs (Chief Financial Officers/Treasures) $\mathrm{N}=30$ throughout Canada and the United Stated of America (USA) with a participant response rate of $\mathrm{N}=13$ or 43\%. Discussion, Implications, Conclusion and Recommendations are also discussed.
\end{abstract}

Keywords: Best Practices, CEO (Chief Executive Officer/President), CAO (Chief Administrative Officer/Executive Secretary), CFO (Chief Financial Officer/Treasurer), Conference, Exemplary, Excellence, General Conference of Seventh-day Adventist(GC), Malcolm Baldridge Award, North American Division of Seventh-day Adventists (NAD), Organizational Effectiveness, Organizational Efficiency, Six Sigma

\section{INTRODUCTION}

"It's not easy to create a success-driven organization ... in fact, it's one of the top challenges business face" (Anonymous, 2015). Wu (2017) highlights a study where business performance is divided into measures of effectiveness and efficiency to evaluate and improve business performance. Sustaining a highly efficient and effective organizational was shown to be an even greater challenge for management and leaders (Nayak, 2017). Organizations in various sectors of diverse domestic and global industries (profit and not-for-profit) (public or private) such as business, education, government, healthcare, military, religious, etc. operate in very competitive environments that require the highest levels of excellence in operational standards and they are expected to meet their industry's management performance expectations (Buckingham and Coffman, 1999). 
Indicators of outstanding organizations (germane to a particular industry) may tend to use performance measurements for efficiency and effectiveness such as an entity's certified audit reports; competitive advantage; financial indicators, market share; growth, expansion and/or retention; profitability; shareholder investment returns; stakeholder engagement, customer satisfaction surveys, human resource productivity analysis, impact of managerial effectiveness and skills and other financial metrics (Muthuveloo, Kang and Teoh, 2017; Soni, K. 2017; Hoffmann, 2017). Benchmarks to achieve these standards may also be found in gold star instruments such as the Best Practices, Malcolm Baldridge Award, and Six Sigma.

The primary purpose in this study is to determine what existing criteria and standards are considered as benchmarks for local SDA conferences aspiring to achieve operational excellence based upon the data obtained from the "experts" in higher organizations who are comprised of CEOs (Presidents), CAOs (Executive Secretaries) and CFOs; (Treasurers) and their evaluation measurements for best practices in organizational effectiveness and efficiency.

\section{LITERATURE}

\section{Best Practices in Organizational Effectiveness and Efficiency}

Quality management in organizations can secure the satisfaction and loyalty of its Stakeholders, and enhance the overall effectiveness and efficiency of the organization (Sadeh, 2017). According to Taylor, Cornelius and Colvin (2014) "leaders with high levels of transformational leadership were predicted to be reported as having more effective organizations". However, leadership and employees in the organization have to be committed to making the necessary operational changes to meet standards of excellence (Goddard and Mkasiwa, 2016).

When employees believe that their organization values their contributions and cares about their welfare; employees will work more efficiently to save the organization time and money.

Organizational policies, procedures, values and interpersonal treatment enhance managerial effectiveness of managers leading to positivity and productivity in organizations (Malbasic, Marimon and Mas-Machuca, 2016; Srivalli and Kota, 2016; Rangriz and Soltanieh, 2015; Yildiz, 2014). Exploring and studying the operational practices of "Good to Great Companies" and other standards of excellence such as the Malcolm Baldridge Award and Six Sigma used by exemplary organizations in their respective industries that constitute "Best Practices" and "Benchmarking" tends to improve the organization's own performance (Dembowski, 2013; Tutie, Zaillnai and Fernando, 2010).

\section{Malcolm Baldridge Award}

The Malcolm Baldrige Award has been referred to as the nation's presidential award for business performance excellence (Anonymous, 2015). Automotive News (2017) highlighted that in 1987 the Malcolm Baldrige Award was established by Congress to recognize companies that excelled in the following seven areas: Leadership, Strategic Planning, Customer and Market Focus, Information and Analysis, Human Resource Focus, Process Management and Business Results recognizing categories in the areas of Manufacturing, Service, Small Business, Education, Health Care and Nonprofit. According to Foma (2012), the Malcolm Baldrige Award, which promotes performance excellence in both the public and private sector of business and organizations, is considered the highest level of achievement and national recognition for performance excellence that an organization in the USA can earn and receive. This award is given to high-performing organizations (Ford, Evans, and Masterson, 2014) who commitment to organizational excellence is reflected in their operating standards and 
performance; and where, according to McManus (2018) a wide range set of assessments and results that are required to demonstrate an organization's excellence.

\section{Six Sigma}

The Six Sigma standards of quality and measurements originated in the manufacturing sector and has expanded to other industries with the primary objective of improving operational performance and competiveness in addition to controlling methods of product process and production (Chakravorty, 2018; Sunder and Shah, 2016). Organizations that utilize Six Sigma assessments and practices tended to experience positive impact on its overall operations in areas of effectiveness, efficiency and reducing operating costs. (Minkin, 2017; Sony and Naik, 2012). However, according to Chakravorty (2018), companies have been significantly challenged implementing Six Sigma tools and methodology to the extent of discontinuing its usage as a result of experiencing negative impacts and results on their company's performance in operatingeffectiveness and efficiency.

\section{RESEARCH DESIGN}

The basis for this qualitative (Creswell, 2014; Patten, 2000) exploration was instigated by sentiments that Seventh-day Adventist (SDA) local conferences may also aspire to emulate standards of excellence that are expected and exemplified in other exemplary organizations. Three critical questions this study addresses are: (1) What are possible criteria and standards of organizational excellence and effectiveness? (2) What comprises an organization's effectiveness system? (3) What are the attributes of an effective and efficient organization? A qualitative design (Elsbach and Bechky, 2009; Eriksson and Kovalainen, 2008; Tharenou, Donohue and Cooper, 2007; Nardi, 2003) was utilized with data for this study selected, collected and analyzed (coding, patterns, trends and themes) from extensive open-ended questionnaires to targeted populations of NAD and Union conference CEOs (Chief Executive Officers/Presidents), CAOs (Chief Administrative Officers/Executive Secretaries) and CFOs (Chief Financial Officers/Treasures) $\mathrm{N}=30$ throughout Canada and the United Stated of America (USA) with a $43 \%$ response rate of $\mathrm{N}=13$ realized.

\section{RESULTS \\ Criterial of Excellence in SDA Local Conferences}

In a prior research study (See Appendix C, Table 5) conducted by Brown (2005), the criteria for determining which local conferences were identified as exemplary; meaning performing in an exceptional manner with excellence, was determined by asking the "experts" who were categorized as higher organization administrators (CEOs/Presidents and CFOs/Treasurers) serving in the Division and Union conferences located in the North American territory; primarily Canada and the United States of America. These entities are entrusted with the responsibilities of overseeing the operations of the local conferences in the SDA organizational system (North American Division Working Policy (2015-2016). 


\section{Research Questions:}

\section{(1)What are possible criteria and standards of organizational excellence and effectiveness?}

\section{Table 1}

\begin{tabular}{|c|l|c|}
\hline \multicolumn{1}{|c|}{ Aggregate of Participant Responses } & $\%$ \\
\hline 1 & A clear, communicative Mission Statement that is understood and fosters commitment. & $77 \%$ \\
\hline 2 & A collaborative leadership team that reflects collegiality, teamwork and good leadership. & $46 \%$ \\
\hline 3 & $\begin{array}{l}\text { Educated trained, developed and empowered personnel properly assigned and placed in the } \\
\text { office and field. }\end{array}$ & $31 \%$ \\
\hline 4 & Financial management, financial solvency and clean audit reports. & $31 \%$ \\
\hline 5 & Measurable Goals & $23 \%$ \\
\hline 6 & Church Growth & $23 \%$ \\
\hline 7 & Integrity & $15 \%$ \\
\hline 8 & Transparency & $15 \%$ \\
\hline 9 & A Clear Vision & $15 \%$ \\
\hline 10 & Process Accountability for employees that is measurable. & $15 \%$ \\
\hline 11 & Diligence & $8 \%$ \\
\hline 12 & Spiritual Orientation & $8 \%$ \\
\hline 13 & Honesty & $8 \%$ \\
\hline 14 & Authenticity & $8 \%$ \\
\hline 15 & Shared Core Values & $8 \%$ \\
\hline 16 & Excellence in work habits. & $8 \%$ \\
\hline 17 & Efficiency & $8 \%$ \\
\hline 18 & Strategic Plan & $8 \%$ \\
\hline
\end{tabular}

\section{(2) What comprises an organization's effectiveness system?}

Table 2

\begin{tabular}{|c|l|c|}
\hline & \multicolumn{1}{|c|}{ Aggregate of Participant Responses } & \% \\
\hline 1 & Mission alignment inclusive of reviewing, fine tuning and understanding mission. & $54 \%$ \\
\hline 2 & Good communication network inclusive of listening to and feedback from employees. & $31 \%$ \\
\hline 3 & Collaborative spirit working together in unity towards the same objectives, etc. & $31 \%$ \\
\hline 4 & Openness to regular assessments and evaluations of all employees' needs and performance. & $31 \%$ \\
\hline 5 & Strategic goals, assessments of goals and is recognizable by results. & $31 \%$ \\
\hline 6 & Financial stability, internal controls, regular reporting. & $31 \%$ \\
\hline 7 & A system that provides oversite and hold players (employees) accountable. & $23 \%$ \\
\hline 8 & $\begin{array}{l}\text { Leaders committed to Christ, His Word, growth, and doing what is right not the popular } \\
\text { thing. }\end{array}$ & $23 \%$ \\
\hline 9 & Strong Executive Board actively involved in organization and governance. & $23 \%$ \\
\hline 10 & Strategic planning & $15 \%$ \\
\hline 11 & Church Growth & $8 \%$ \\
\hline 12 & Transparency in planning. & $8 \%$ \\
\hline 13 & Experience in all realms or facets of the operations. & $8 \%$ \\
\hline 14 & Intentionality if (in) bring fresh people in system. & $8 \%$ \\
\hline 15 & Very clear succession plan. & $8 \%$ \\
\hline 16 & Administrator that can cast a clear vision. & $8 \%$ \\
\hline 17 & $\begin{array}{l}\text { Ensuring that financial resources are used on critical mission areas such as evangelism, } \\
\text { education and pastoral development. }\end{array}$ & $8 \%$ \\
\hline
\end{tabular}




\section{(3) What are the attributes of an effective and efficient organization?}

Table 3

\begin{tabular}{|c|l|c|}
\hline & \multicolumn{1}{|c|}{ Aggregate of Participant Responses } & \multicolumn{1}{|c|}{} \\
\hline 1 & A stable organization understanding, focused and committed to mission. & $54 \%$ \\
\hline 2 & Proper financial management and focus resources on mission as its priority. & $46 \%$ \\
\hline 3 & $\begin{array}{l}\text { The ongoing collaboration and working together of conference leaders, employees and } \\
\text { board of directors. }\end{array}$ & $31 \%$ \\
\hline 4 & Accountability where everyone is accountable to someone else. & $31 \%$ \\
\hline 5 & Clear communication of organization's strategic plan, goals, and operations, etc. & $31 \%$ \\
\hline 6 & $\begin{array}{l}\text { Leadership that is willing to listen to different points of view; and take advice/council and } \\
\text { learn from others. }\end{array}$ & $23 \%$ \\
\hline 7 & Ability to react to outside pressures and to meet challenges as opportunities for growth. & $15 \%$ \\
\hline 8 & Strict adherence to "best practices". & $15 \%$ \\
\hline 9 & Recognition and celebration of big and small achievement by administration and fellow & $15 \%$ \\
\hline 10 & Leadership Transparency & $15 \%$ \\
\hline 11 & Training, Mentorship and Youth Empowerment & $15 \%$ \\
\hline 12 & Flexibility & $8 \%$ \\
\hline 13 & Being able to pivot away from non-productive activity to efficient methods. & $8 \%$ \\
\hline 14 & Right sizing for growth. & $8 \%$ \\
\hline 15 & No nepotism or favoritism involved. & $8 \%$ \\
\hline 16 & Following policies & $8 \%$ \\
\hline 17 & Everyone at every level know their role. & $8 \%$ \\
\hline 18 & Outcomes more positive than negative. & $8 \%$ \\
\hline 19 & Leadership who is willing to let others fail at times. & $8 \%$ \\
\hline 20 & Leadership that is humble. & $8 \%$ \\
\hline 21 & $\begin{array}{l}\text { Open dialogue is encouraged and occurs with administration and fellow employees without } \\
\text { fear of retribution or ridicule. }\end{array}$ & $8 \%$ \\
\hline
\end{tabular}

\section{(4) Additional Criteria for an Exemplary Local Conference}

Table 4

\begin{tabular}{|c|l|c|}
\hline & \multicolumn{1}{|c|}{ Aggregate of Participant Responses } & \multicolumn{1}{|c|}{} \\
\hline 1 & Mission Orientation & $8 \%$ \\
\hline 2 & $\begin{array}{l}\text { Spirit of cooperation between employees with leadership to build up the work in their field } \\
\text { of labor. }\end{array}$ & $8 \%$ \\
\hline 3 & Strong spiritual positioning by organizing, deputizing, and mobilizing prayer ministries. & $8 \%$ \\
\hline 4 & Teamwork & $8 \%$ \\
\hline 5 & Unity of purpose among the administrators. & $8 \%$ \\
\hline 6 & Communication & $8 \%$ \\
\hline 7 & A smooth operation. & $8 \%$ \\
\hline 8 & In touch with the field. & $8 \%$ \\
\hline 9 & Integrity & $8 \%$ \\
\hline 10 & Accounting and finance expertise in treasury. & $8 \%$ \\
\hline 11 & Vision Oriented Leadership. & $8 \%$ \\
\hline
\end{tabular}

In summary, the perspectives of the higher level division and union "experts" participants on these research questions varied with a wide range of thoughts and insights in their responses on their perspectives on what comprises and constitutes the attributes, criteria, standards of organizational excellence, efficiency and effectiveness. The differences highlighted in the tables may tend to be reflective of the participants diverse demographic educational background and/or professional years experiences in local conference and/or higher level administration which may tend to impact the depth of leadership thought and analysis when asked to assess or articulate measurements and standards in the realm of their leadership influence and responsibility. 
The most consistent and highest percentage of re-occurring themes and patterns of thought from the "experts" reflected in their responses to the questions tended to involve (1) Mission Emphasis, Focus and Vision, (2) Collaboration, Teamwork, Collegiality and Good Leadership, (3) Financial Solvency and Management, (4) Accountability of all employees inclusive of meaningful assessments and evaluation that foster professional and personal growth, and (5) Effective leadership and organizational communication that reflects measurable goals and plans.

\section{DISCUSSION AND IMPLICATIONS}

Operational excellence in every aspects of a conference operation should be the minimum goal. Organizational effectiveness and efficiency is vital to success in achieving and fulfilling the vison and mission which governs the institution. Having benchmarks and understanding what criteria and standards are used as measurements by higher organizations responsible for conference evaluations and governance will ensure that conferences are able to meet those standards of excellence and receive accurate and consistent recognition, rewards and incentives for obtaining and maintaining excellence. Secondly, unified benchmarks, criteria and standards for excellence can be adopted as divisional operating policies, and shared with the global conferences to consider in a similar fashion pertaining to excellence. Thirdly, local conference top management (CEOs, CAOs, CFOs, and VPs), Governing Executive Board, constituent members and stakeholders will have benchmarks, criteria and standards that may be effectively utilized as accountability measures and to govern expectations. Fourthly, whereas North American business and organizational operating models tend to effect global standards, so may the NAD conference criteria and standards for operating excellence effect the other global divisions in the Adventist world church system.

\section{CONCLUSIONS}

The desire and necessity for operational excellence in SDA conferences should not be anything less than what is expected in the public and private sectors of business and organizations. In fact the Adventist criteria and standards for operational effectiveness, efficiency and excellence should exceed the world's; and must be higher because we are told by God, who is the head of the Church in the person of Jesus Christ, that we are to the be head and not the tail (Deuteronomy 28:13 KJV), the light of the world and the salt of the earth (Matthew 5:13-16 KJV). May all conferences strive to meet that objective and purpose!

\section{RECOMMENDATIONS}

1. The criteria and standards shared in this study should be carefully reviewed by higher level NAD and Union administrators and ideas of "best practices" should be adopted in the NAD Policy Book as benchmarks and reviewed and revised periodically on a $5-10$ year basis for continuous improvement after further dialogue and approve from local conference administrators.

2. Communication should be facilitated by NAD and/or Union leadership with local conference leadership and key stakeholders (employees, executive board and constituency) pertaining to the criteria and standards for organizational excellence, efficiency and effectiveness from this study in a forum where their feedback and input can be received to ensure stakeholder knowledge, understanding and acceptance of operational benchmarks that will be uniform across the NAD local conferences for conference assessment, evaluation and strategic planning.

3. The establishment of clearly defined and agreed upon benchmarks and "best practices" for local conference operations should be implemented in the GCAS audit process and should reflect a review of the NAD policy criteria as a standard for effectiveness and 
efficiency. Systems and standards for evaluation should be put in place that are viable, attainable, measurable and implementable and timely.

4. Engage the research to further discuss and explore this study in an NAD forum with Division, Union and Conference leaders in a more intensive thought process of perspectives, dialogue and feedback; and to extrapolate anything other criteria, standards or ideas that may have been missed from non-respondent "experts" invited to participate in the survey.

\section{References}

Anonymous. (2015, November). Design a better workplace. Credit Union Magazine; Madison. 81.11:12.

Automotive News (2017). Lauding Leadership. Automotive News, 00051551, 1/30/2017, Vol. 91, Issue 6762.

Brown, T. (2005). A study of the expectations of treasurers as chief financial officers in local conferences in the north American division of seventh-day Adventist: Perceptions of roles, responsibilities and relationships. Andrews University. Berrien Springs, MI. Dissertation.

Buckingham, M. and Coffman, C. (1999). First break all the rules: What the world's greatest managers do differently. New York: Simon \& Schuster.

Creswell, J. (2014). Research design: Qualitative, quantitative, and mixed methods approaches (4th ed.). Thousand Oaks, CA: Sage.

Chakravorty, S.S. (2018, January). Gain speed by losing tools: Sometimes six sigma is more of an albatross than a solution. Industrial Engineer: IE. Vol. 50 Issue 1, p37-42. 6p.

Dembowski, F.L. (2013, January). The roles of benchmarking, best practices and innovations in organizational effectiveness. International Journal of Organizational Innovation (Online); Hobe Sound. 5.3: 6-20.

Elsbach, K.D. and Bechky, B.A. (2009). Qualitative Organizational Research (Vol. 2). Charlotte, NC. Information Age Publishing, Inc.

Eriksson P. and Kovalainen, A. (2008). Qualitative Methods in Business Research. Thousand Oaks, CA: Sage.

Foma, E. (2012) Talking of malcolm baldrige national quality award. Review of Integrative Business and Economics Research; Hong Kong. 1.1:221-231.

Ford, M.W., Evans, J.R. and Masterson, S.S. (2014). An information processing perspective of process management: Evidence from baldrige award recipients. The Quality Management Journal; Milwaukee. 21.1:25-41.

Goddard, A. and Mkasiwa, T.A. (2016). New public management and budgeting practices in tanzanian central government: "Struggling for conformance". Journal of Accounting in Emerging Economies; Bingley. 6.2:340-371.

Hoffmann, T. (2017, Spring). Building the efficient and effective professional firm - part I: Financial metrics. Journal of Pension Benefits: Issues in Administration. Vol. 24 Issue 3, p21-25. 5p.

Malbasic, I. Marimon, F and Mas-Machuca, M. (2016). Is it worth having focused values? Management Decision; London. 54.10:2370-2392.

McManus, K. (2018). Making a data point. ISE Magazine; www.iise.org/ISEmagazine.

Minkin, S.J. (2017, Spring). Lean six sigma: Saving more than just money. Armed Forces Controller. Vol. 62 Issue 2, p17-20.4p.

Muthuveloo, R., Kang, C. C. and Teoh, A. P. (2017). An empirical analysis of the perceived skills in predicting managerial effectiveness: The malaysian perspective. Global Business \& Management Research. Special Issue, Vol. 9, p41-59. 19p.

Nardi, P.M. (2003). Doing Survey Research: A Guide to Quantitative Methods. Boston, MA. Allyn and Bacon.

Nayak, A KJR. (2017, March). Efficiency, effectiveness and sustainability: The basis of competition and cooperation. Vilakshan: The XIMB Journal of Management. Vol. 14 Issue 1, p111-118. 8p.

North American Division Working Policy (2015-2016). North American Division of the General Conference; Silver Springs, MD.

Patten, M.L. (2000). Understanding research methods: An overview of the essentials ( $2^{\text {nd }}$ ed.). Los Angeles, CA: Pyrczak Publishing. 
Rangriz, H. and Soltanieh, F. (2015). Exploring the effects of organisational capabilities and managerial competencies on the organisational effectiveness. Journal of Strategic Human Resource Management; New Delhi. $4.2: \mathrm{n} / \mathrm{a}$.

Sadeh, E. (2017). Interrelationships among quality enablers, service quality, patients' satisfaction and loyalty in hospitals. TQM Journal. Bingley. 29:101-117.

Soni, K. and Rastogi, R. (2017). Impact of psychological capital on organizational effectiveness: Role of positive psychology at work. Journal of Organisation \& Human Behaviour. Vol. 6 Issue 1/2, p1-9. 9p.

Sony, M., and Naik, S. (2012). Six sigma, organizational learning and innovation. The International Journey of Quality \& Reliability Management; Bradford. 29.8:915-936.

Srivalli, P., Kota, N M K. (2016). Journal of Organization and Human Behaviour; New Delhi. 5.1:n/a.

Sunder, V. and Shah, S. (2016, February). A secured approach to managing stakeholders in lean six sigma projects: Role call! Quality Progress; Milwaukee. 49.2:44-49.

Taylor, C. M., Cornelius, C.J. and Colvin, K. (2014). Visionary leadership and its relationship to organizational effectiveness. Leadership \& Organization Development Journal; Bradford. 35.6:583-566.

Tharenou, P, Donohue, R. and Cooper, B. (2007). Management Research Methods. New York, NY. Cambridge University Press.

Tutie, A., Zailani, S. and Fernando, Y. (2010). Best practices for the effectiveness of benchmarking in the indonesian manufacturing companies. Benchmarking; Bradford. 17.1:115-143.

Yildiz, E. (2014). A study on the relationship between organizational culture and organizational performance and a model suggestion. International Journal of Research in Business and Social Science; Istanbul. 3.4: 52-67.

Wu, G-C. (2017, November). Environmental innovation approaches and business performance: effects of environment regulations and resource commitment. Innovation: Management, Policy \& Practice. Vol. 19 Issue 4 , p.407-427. 21p.

\section{APPENDIX A}

PARTICIPANT'S DEMOGRAPHICS SUMMARY

Purposeful Sample Participant Population N=30 (100\%)

Participant Responses N=13 (43\%)

\section{Territory: Canada, United States of America (USA)}

Entities: North American Division and Union Conferences

Participant Experts:

$$
\begin{aligned}
& \text { President 5/10 (50\%) } \\
& \text { Executive Secretary 4/10 (40\%) } \\
& \text { Treasurer 4/10 (40\%) }
\end{aligned}
$$

Years of Experience in Current Position: $1-_{-}\{6\}_{-} 6-10_{-}\{6\}_{-} 11-15_{-}\{1\}_{-} 16+$ Years of Administrative Experience: $1-_{-}{ }_{-}\{2\}_{-} 6-10_{-}\{1\}_{-} 11-15_{-}\{1\}_{-} 16-20_{-}\{5\}_{-} 21+_{-}\{4\}_{-}$ Highest Degree Earned: Associates ___ Bachelors _ 3 __ Masters _5_ Doctorate _ 5 


\section{APPENDIX B \\ DETAILED PARTICIPANT RESPONSES}

\section{RESEARCH QUESTIONS}

\section{What are possible criteria and standards of organizational excellence and effectiveness? \\ President Responses}

Integrity

Transparency

Diligence

Spiritual Orientation

Measurable Goals

A mission statement that is accompanied by a strategic plan that has a buy-in by your team.

A clear vision and mission

A collaborative leadership team

A trained staff in office and field

If we are following the mandate to spread the gospel then we should expect growth in the body

of believers.

Financial Solvency

A Spirit of Collegiality

Commitment to the mission

Clear articulation of the vision to facilitate the mission

Strategic planning and correct assignment of gifted personnel and experienced personnel in all areas of activity.

\section{Executive Secretary Responses}

Conference growth

Mission attitude around the field

Clear understanding of mission

Understanding the purpose of the organization

Honesty

Integrity

Authenticity

An understanding of and functional collaboration to the organizations mission.

Shared core values

Respect for other employees and an appreciation for what they bring to the table.

Good leadership (If leadership is poor, the organization will be poor)

\section{Treasurer Responses}

Well educated staff who keeps up with industry

Excellence in work habits

Ability to create and follow a budget annually

Mission focus

Process accountability for all employees that is measurable.

Unmodified (clean) audit opinion

Membership growth

Financial goals that can be measured by days of cash, working capital, and a strong balance sheet to be able to accomplish the mission of the organization.

Accountability

Transparency 


\section{Efficiency}

Teamwork

Employee development and empowerment

\section{What comprises an organization's (conference) effectiveness system?}

\section{President Responses}

Good Communication Network

Collaborative Spirit

Openness to Evaluation and Potential Changes

A system that hold the players accountable

Where each entity is moving in the same direction

If an organization is successful if (it) will be recognized by its results.

Financial stability

Church growth

There needs to be adequate and effective oversight of pastors and teachers and departmental personnel.

Conference officers should meet regularly with conference employees to assess their needs.

Transparency in planning

Regular evaluations

Leadership that listens to those being led

Experience in all realms or facets of the operations

\section{Executive Secretary Responses}

Accountability to mission

Growth of individual leaders

Intentionality if bring fresh people in system

Mission alignment

Very clear succession plan

Strategic planning

Unity of purpose

Periodic reviews of Mission statement and its meaning

Assessment as to how function is measuring up to mission

Feedback from those who are to be served

Leadership that is committed to Christ and his word

A mission statement that is short, memorable and is finely tuned.

Strategic goals and plans that reflect the mission statement.

\section{Treasurer Responses}

Working together

Strong Executive Committee

Regular financial reporting

Ability of senior administration to evaluate and communicate trends to its governing body.

Administrator that can cast a clear vision/mission.

Involved board

Goals with accountability

Leaders willing to do the right thing not the popular thing

Stream lining internal controls

Ensuring that financial resources are used on critical mission areas such as evangelism, education and pastoral development. 


\section{What are the attributes of an effective and efficient organization (conference)? President Responses}

Flexibility

Ongoing collaboration before conference officials, board of directors, church pastors, and local teachers and laypersons.

Proper financial boss (focus) where mission is priority; fairness and balance is achieved.

A stable organization that is focused on mission.

Maintaining a balanced budget.

Having a staff who are clear of (on) the goals of the organization.

Ability to react to outside pressures and to meet challenges as opportunity for growth.

Being able to pivot away from non-productive activity to efficient methods.

Right sizing for growth

No nepotism or favoritism involved

Strict adherence to "best practices"

Following of policies

Mission driven

\section{Executive Secretary Responses}

High percentage of resources going to frontline mission.

Everyone at every level knows their role.

Everyone understands the mission of the organization.

Everyone is accountable to someone else.

Recognition and celebration of big and small achievement by administration and fellow employees.

Open dialogue is encouraged and occurs with administration and fellow employees without fear of retribution or ridicule.

Outcomes more positive than negative

Leadership and staff that has brought into the mission and strategic goals and plans of the organization.

Leadership and staff that is committed to excellence.

Leadership that is willing to listen to different points of view.

Leadership who is willing to take advice and/or council.

Leadership that is willing to learn from its mistakes and/or failures and is willing to let others fail at times.

Leadership that is not threatened when challenges occur.

Leadership that is humble.

Leadership that is willing to give credit to others when credit is due.

\section{Treasurer Responses}

Sound budget and stay with it.

Working together

Transparency

Manage finances

Mission focus

Accountability

Clear organizational communication

Collaboration between administration/leadership and rank and file employees.

Transparency from leaders

Accountability from leaders 
Leaders that provide a clear mission for the organization and communicates that throughout the organization.

Provide an action plan to accomplish the mission with a measurement of the performance.

Cost management

Training and Mentorship

Accountability

Youth Empowerment

\section{Additional Criteria for an Exemplary Local Conference President(s) Responses}

Mission Orientation

Needs to be a spirit among employees that they cooperate with leadership to build up the work in their field of labor.

Strong spiritual positioning by organizing, deputizing, and mobilizing prayer ministries.

\section{Executive Secretary Responses}

Teamwork

Unity of purpose among the administrators

\section{Treasurer Responses}

Communication

A smooth operation

In touch with field

Integrity

Accounting and finance expertise in treasury

Vision oriented leadership 


\section{APPENDIX C \\ SUMMARY OF CRITERIA FOR EXEMPLARY LOCAL CONFERENCES}

\section{Summary of Criteria for Exemplary Conference Reported by NAD and Union Presidents and Treasurers (Brown, 2005)}

Table 5

\begin{tabular}{|c|c|c|c|}
\hline Analysis of Criterial Listing and Responses & $\begin{array}{c}\text { \% of } \\
\text { Presidents }\end{array}$ & $\begin{array}{c}\text { \% of } \\
\text { Treasurers }\end{array}$ & $\begin{array}{c}\text { Total \% of } \\
\text { Participants }\end{array}$ \\
\hline $\begin{array}{l}\text { Financial Stability (Whole financial operating and statement } \\
\text { picture soundness) }\end{array}$ & $44 \%$ & $90 \%$ & $68 \%$ \\
\hline Emphasis On Soul-Winning & $44 \%$ & $40 \%$ & $42 \%$ \\
\hline Strong Administrative Team (clear goals \& objectives) & $33 \%$ & $50 \%$ & $42 \%$ \\
\hline $\begin{array}{l}\text { Emphasis placed on being loyal and supportive of various facts } \\
\text { of mission of the organization. }\end{array}$ & $33 \%$ & $40 \%$ & $37 \%$ \\
\hline On-Time Reporting & $22 \%$ & $30 \%$ & $26 \%$ \\
\hline Develops an atmosphere of congeniality and camaraderie. & $11 \%$ & $40 \%$ & $26 \%$ \\
\hline $\begin{array}{l}\text { Well defined mission focus which enables and fosters ministry } \\
\text { by the local congregation. }\end{array}$ & $11 \%$ & $20 \%$ & $16 \%$ \\
\hline Clearly communicate with employees and constituents. & $11 \%$ & $20 \%$ & $16 \%$ \\
\hline Strategic planning is evident and pervasive in the organization. & $11 \%$ & $20 \%$ & $16 \%$ \\
\hline An effective and strong educational school system. & $11 \%$ & $20 \%$ & $16 \%$ \\
\hline Good support from the conference to the local church. & $11 \%$ & $10 \%$ & $11 \%$ \\
\hline Conference vision of goals and objectives. & $22 \%$ & $0 \%$ & $11 \%$ \\
\hline $\begin{array}{l}\text { Strong stewardship program in conference where members } \\
\text { are educated in stewardship education. }\end{array}$ & $22 \%$ & $0 \%$ & $11 \%$ \\
\hline $\begin{array}{l}\text { The conference must have a service focus on their constituents } \\
\text { and there must be a priority to their constituency. }\end{array}$ & $0 \%$ & $20 \%$ & $11 \%$ \\
\hline Adequate plan for mentoring of conference workers. & $11 \%$ & $10 \%$ & $11 \%$ \\
\hline Growth pattern of Conference field. (Membership, etc.) & $11 \%$ & $10 \%$ & $11 \%$ \\
\hline Spiritual Leadership & $20 \%$ & $0 \%$ & $11 \%$ \\
\hline Works budget process. & $11 \%$ & $10 \%$ & $11 \%$ \\
\hline Numerical membership growth. & $11 \%$ & $10 \%$ & $11 \%$ \\
\hline $\begin{array}{l}\text { Care about people and not just policies (members, and non- } \\
\text { Adventists). }\end{array}$ & $11 \%$ & $10 \%$ & $11 \%$ \\
\hline Strong departmental programs that facilitate church growth. & $11 \%$ & $10 \%$ & $11 \%$ \\
\hline
\end{tabular}

\section{Notes:}

A. This criteria list was generated from the survey responses of the NAD and Union presidents and treasurers for identification of exemplary conferences.

B. A total of 10 presidents and 10 treasurers were sent survey forms. 9 presidents and 10 treasurers responded for a total of 19 and a 95\% response rate.

C. Data analysis is based on a total of 19 survey response forms received.

D. *Summary Chart represents survey responses from at least two participants. Detailed chart reflected in reference (Brown, 2005). 